\title{
EKSPERIMENTASI TAPPS DAN GI TERHADAP PENGETAHUAN DAN SIKAP SOSIAL DITINJAU DARI GAYA BELAJAR
}

\author{
Ek Ajeng Rahmi Pinahayu ${ }^{1}$, Nur Alamsyah ${ }^{2}$, Risma Nurul Auliya ${ }^{3}$, Luh Putu Widya Adnyani ${ }^{4}$ \\ Program Studi Teknik Informatika, Universitas Indraprasta PGRI ${ }^{1,2,3,4}$ \\ Email: ekajeng_rahmipinahayu@yahoo.com
}

\begin{abstract}
Abstrak
Pendidikan dihadapkan pada permasalahan multi dimensi, di antaranya rendahnya kompetensi pengetahuan matematika dan krisis aspek sosial. Penelitian ini bertujuan untuk mengetahui perbedaan pengaruh model Thinking Aloud Pair Problem Solving (TAPPS), Group Investigation (GI), dan Konvensional terhadap kompetensi pengetahuan dan sikap sosial ditinjau dari gaya belajar. Jenis penelitian eksperimental semu, dengan populasi seluruh siswa kelas VIII SMP Negeri 24 Jakarta. Pengujian hipotesis menggunakan analisis multivariat dua jalan dengan sel tak sama. Hasil penelitian di antaranya: (1) TAPPS menghasilkan kompetensi pengetahuan lebih baik dari GI dan konvensional, serta GI lebih baik dari konvensional, (2) TAPPS dan GI menghasilkan sikap sosial yang sama, dan keduanya lebih baik dari konvensional, (3) visual dan auditorial menghasilkan kompetensi pengetahuan yang sama baiknya, dan keduanya lebih baik dari kinestetik, (4) visual dan auditorial menghasilkan sikap sosial yang sama baiknya, dan keduanya lebih baik dari kinestetik, (5) TAPPS dan GI, kompetensi pengetahuan ketiga gaya belajar sama baiknya, sedangkan konvensional terdapat perbedaan, (6) TAPPS dan GI, sikap sosial ketiga tipe gaya belajar sama baiknya, sedangkan konvensional terdapat perbedaan, (7) pada visual dan auditorial, kompetensi pengetahuan ketiga model sama, sedangkan kinestetik terdapat perbedaan, dan (8) pada visual dan auditorial, sikap sosial ketiga model sama, sedangkan kinestetik terdapat perbedaan.
\end{abstract}

Kata Kunci : Thinking Aloud Pair Problem Solving, Group Investigation, Gaya Belajar, Sikap Sosial, Analisis Multivariat

\begin{abstract}
Education is faced with multi-dimensional problems, including the low competence of mathematical knowledge and the crisis of social aspects. This study aims to determine the difference in the effect of Thinking Aloud Pair Problem Solving (TAPPS), Group Investigation (GI), and Conventional models on knowledge competence and social attitudes in terms of learning styles. This is a quasi-experimental research, with a population of all eighth-grade students at SMP Negeri 24 Jakarta. Hypothesis testing used two-way multivariate analysis with unequal cells. The results of the research included: (1) TAPPS produced knowledge competence better than GI and conventional, and GI was better than conventional, (2) TAPPS and GI produced the same social attitudes, and both were better than conventional, (3) visual and auditorial resulted in the same good knowledge competence, and both were better than kinesthetic, (4) visual and auditory produced the same good social attitudes, and both were better than kinesthetic, (5) TAPPS and GI, knowledge competence of the three learning styles were equally good, whereas conventionally there were differences, (6) TAPPS and GI, social attitudes of the three types of learning styles were equally good, while conventionally there were differences, (7) in visual and auditory, knowledge competence of the three models were the same, while there were differences in kinesthetic, and (8) in visual and auditory, the social attitudes of the three models were the same, while there were differences in kinesthetic.
\end{abstract}

Key Words : Thinking Aloud Pair Problem Solving, Group Investigation, Learning Styles, Social Attitudes, Multivariate Analysis

\section{PENDAHULUAN}

Kualitas pendidikan tidak hanya dapat dicapai dengan mereformasi tujuan dan muatan kurikulum saja, tetapi perlu memperbaiki strategi pembelajaran di sekolah. Pembelajaran yang biasa dipakai sering disebut sebagai model pembelajaran konvensional, siswa tidak diberi 
kesempatan untuk membangun sendiri pengetahuannya, sehingga siswa tidak mudah ingat. Pendidikan matematika saat ini masih belum menampilkan tercapainya tujuan pendidikan matematika secara optimal. Hasil survei TIMSS menunjukkan kemampuan siswa Indonesia dalam pendidikan matematika masih sangat jauh dari rata-rata Internasional [1]. Berkaca pada hasil TIMSS, sebaiknya dijadikan gambaran atau bahan penilaian pendidikan dan respon pemerintah untuk lebih meningkatkan pembelajaran [2]. Selain rendahnya kompetensi pengetahuan matematika, saat ini bangsa Indonesia juga dihadapkan pada permasalahan lainnya. Seperti halnya krisis pada aspek sosial dan akhlak. Sikap tidak dapat diungkapkan dengan kata-kata oleh seseorang tetapi hanya bisa diperhatikan oleh orang tersebut [3]. Berbagai media sosial serta kenikmatan modernisasi lainnya, membawa pengaruh pada perkembangan sikap sosial, seperti perubahan menjadi individu yang mementingkan diri sendiri, menurunkan kualitas interaksi sosial antar satu dengan lainnya serta munculnya sikap sosial negatif [4]. Sikap sosial perlu ditanamkan pada siswa di sekolah [3]. Sikap positif siswa terhadap matematika menjadi salah satu faktor pendukung keberhasilan dalam belajar matematika [5].

Dari beberapa permasalahan di atas, peneliti mencoba menerapkan pembelajaran di kelas yang didasarkan teori konstruktivisme. Penelitian menunjukkan bahwa model pembelajaran kooperatif dapat meningkatkan sikap sosial, sikap spiritual dan prestasi belajar [6]. Model yang diterapkan yaitu model pembelajaran kooperatif tipe Think Aloud Pair Problem Solving (TAPPS) dan Group Investigation $(G I)$. Dalam model kooperatif TAPPS, 2-4 siswa secara aktif bekerja sama menyelesaikan masalah kemudian dibagi menjadi dua pihak, satu pihak menjadi problem solver dan lainnya menjadi listener. Model pembelajaran ini memungkinkan siswa saling bertukar strategi dalam menyelesaikan masalah yang mengakibatkan setiap anggota kelompok memiliki kesempatan untuk meningkatkan kemampuan pemecahan masalah matematisnya [7]. Group Investigation merupakan model yang memadukan prinsip belajar kooperatif dengan pembelajaran berbasis konstruktivisme dan prinsip pembelajaran inovatif [8]. Banyak hal yang mempengaruhi hasil belajar, salah satunya adalah gaya belajar. Gaya belajar yaitu cara unik dan konsisten siswa menyerap dan mengolah informasi yang didapat. Gaya belajar dikelompokkan menjadi visual, auditorial dan kinestetik [9]. Siswa visual lebih memanfaatkan penglihatan, siswa auditorial memanfaatkan indera pendengaran untuk mempermudah proses belajar, dan siswa kinestetik lebih mudah menyerap informasi dengan bergerak, berbuat dan menyentuh sesuatu yang memberikan informasi agar ia bisa mengingatnya [10].

Penelitian terdahulu menyatakan bahwa guru sebaiknya dapat memilih model pembelajaran yang tepat untuk meningkatkan kemampuan siswa [11]. Persamaan dengan penelitian yang dilakukan oleh peneliti di antaranya menggunakan quasi eksperimental design, analisis multivariat dua jalan, variabel bebas model pembelajaran dan gaya belajar siswa, serta variabel terikat yaitu kompetensi pengetahuan dan sikap sosial siswa. Perbedaan dengan penelitian ini ialah model pembelajaran yang diterapkan serta populasi yang diambil. Pada penelitian sebelumnya menggunakan model Discovery Learning, Problem Based Learning dan Think Pair Share dengan Pendekatan Saintifik. Sedangkan dalam penelitian ini model Think Aloud Pair Problem Solving (TAPPS), Group Investigation (GI), dan Konvensional. 
Tujuan dari penelitian ini ialah untuk mengetahui: (1) manakah kompetensi pengetahuan yang lebih baik antara siswa yang diberikan model TAPPS, GI, atau konvensional, (2) manakah kompetensi sikap sosial yang lebih baik antara siswa yang diberikan model TAPPS, GI, atau konvensional, (3) manakah kompetensi pengetahuan yang lebih baik antara siswa tipe visual, auditorial, atau kinestetik, (4) manakah kompetensi sikap sosial yang lebih baik antara siswa dengan tipe visual, auditorial, atau kinestetik, (5) manakah kompetensi pengetahuan yang lebih baik, siswa tipe visual, auditorial, atau kinestetik, pada masing-masing model, (6) manakah kompetensi sikap sosial yang lebih baik, siswa tipe visual, auditorial, atau kinestetik, pada masing-masing model, (7) manakah kompetensi pengetahuan yang lebih baik, siswa yang diberikan model TAPPS, GI, atau konvensional, pada masing-masing tipe gaya belajar, (8) manakah kompetensi sikap sosial yang lebih baik, siswa yang diberikan model TAPPS, GI, atau konvensional, pada masing-masing tipe gaya belajar.

Hasil penelitian ini diharapkan dapat melengkapi khasanah teori pada pembelajaran matematika yang berkaitan dengan pembelajaran menggunakan model pembelajaran TAPPS dan GI yang ditinjau dari gaya belajar siswa, serta pengaruhnya terhadap kompetensi pengetahuan dan sikap sosial siswa pada pembelajaran matematika. Penelitian ini penting agar pendidik dapat mempersiapkan model pembelajaran yang dapat mengakomodasi semua jenis gaya belajar siswa, serta dalam rangka meningkatkan keterlibatan dan sikap sosial dalam kegiatan pembelajaran.

\section{METODE}

Penelitian ini merupakan penelitian eksperimental semu (quasi eksperimental research), dengan variabel bebas model pembelajaran dan gaya belajar serta variabel terikat kompetensi pengetahuan dan sikap sosial siswa. Digunakan eksperimental semu karena peneliti tidak mungkin mengontrol semua variabel. Populasi dalam penelitian ini adalah seluruh siswa kelas VIII SMP Negeri 24 Jakarta Tahun 2017 yang terdiri dari 7 kelas. Sampel diambil dengan menggunakan Cluster Random Sampling, maka terpilih 3 kelas.

Metode pengumpulan data dengan dokumentasi, angket, tes, dan observasi. Sebelum melakukan eksperimen, dilakukan uji keseimbangan terhadap kemampuan awal siswa menggunakan Multivariate Analysis of Variance (MANOVA) satu jalur yang sebelumnya diuji dulu dengan uji normalitas multivariat dan uji kesamaan variansi dan kovariansi. Uji hipotesis dilakukan menggunakan Two-Way MANOVA dengan desain faktorial $3 \times 3$. Jika hasil analisis variansi menunjukkan bahwa $H_{0}$ ditolak, maka dilakukan uji lanjut yaitu uji Analysis of Variance (ANOVA). Apabila $H_{0}$ ditolak, dilanjutkan kembali menggunakan uji komparasi ganda menggunakan metode Scheffe'.

\section{HASIL DAN PEMBAHASAN}

Hasil uji prasyarat menyimpulkan bahwa semua sampel berasal dari populasi yang berdistribusi normal serta populasi memiliki variansi dan kovariansi yang sama untuk MANOVA serta variansi yang sama untuk ANOVA. Hasil uji keseimbangan dilakukan untuk mengetahui apakah populasi ketiga kelompok model pembelajaran TAPPS, GI, dan Konvensional mempunyai kemampuan awal yang sama. Berdasarkan hasil uji keseimbangan, disimpulkan bahwa populasi ketiga kelompok dalam keadaan seimbang. Selanjutnya, dilakukan uji hipotesis dengan hasil berikut. 
Tabel 1. Rangkuman MANOVA Dua Jalan dengan Sel Tak Sama

\begin{tabular}{|c|c|c|c|c|c|}
\hline Sumber & \multicolumn{2}{|c|}{ Matriks SSCP } & $F_{\text {obs }}$ & $F_{\text {tabel }}$ & Keputusan \\
\hline Faktor $A$ (Model & {$[5384,71$} & 1632,10 & & & \\
\hline Pembelajaran) & 1632,10 & 734,13 & 10,041 & 2,420 & $H_{0}$ ditolak \\
\hline Faktor $B$ & {$[1737,85$} & $1595,11]$ & & & \\
\hline (Gaya Belajar) & 1595,11 & 1547,33 & 7,834 & 2,420 & $H_{0}$ ditolak \\
\hline$A B$ & {$[1766,40$} & $1555,47]$ & & & \\
\hline (Interaksi) & 1555,47 & 1405,91 & 3,688 & 1,988 & $H_{0}$ ditolak \\
\hline $\begin{array}{c}\text { Residual } \\
\text { (error) }\end{array}$ & {$\left[\begin{array}{c}15185,41 \\
494,29\end{array}\right.$} & $\begin{array}{c}494,29 \\
5814,41\end{array}$ & - & - & - \\
\hline $\begin{array}{c}\text { Total } \\
\text { (corrected) }\end{array}$ & {$\left[\begin{array}{c}24074,37 \\
5276,96\end{array}\right.$} & $\begin{array}{l}5276,96 \\
9501,78\end{array}$ & - & - & - \\
\hline
\end{tabular}

Berdasarkan Tabel 1 di atas, terdapat perbedaan efek model pembelajaran, efek gaya belajar maupun interaksi model pembelajaran dan gaya belajar terhadap kompetensi pengetahuan dan sikap sosial. Selanjutnya dilakukan uji lanjut pasca MANOVA berikut.

Tabel 2. Rangkuman Uji Lanjut dengan ANOVA Dua Jalan dengan Sel Tak Sama

\begin{tabular}{|c|c|c|c|c|c|c|c|}
\hline Variabel Terikat & Sumber & $J K$ & $d k$ & $R K$ & $F_{o b s}$ & $\boldsymbol{F}_{\alpha}$ & Keputusan \\
\hline \multirow{4}{*}{$\begin{array}{l}\text { Kompetensi Pengetahuan } \\
\text { Matematika Siswa }\end{array}$} & $\begin{array}{c}\text { Faktor } A \text { (Model } \\
\text { Pembelajaran) }\end{array}$ & 7894,70 & 2 & 3947,35 & 24,435 & 3,093 & $H_{0}$ ditolak \\
\hline & $\begin{array}{c}\text { Faktor } B \\
\text { (Gaya Belajar) }\end{array}$ & 2735,70 & 2 & 1367,85 & 8,467 & 3,093 & $H_{0}$ ditolak \\
\hline & Interaksi $A B$ & 2677,26 & 4 & 669,32 & 4,143 & 2,469 & $H_{0}$ ditolak \\
\hline & $\begin{array}{l}\text { Residual } \\
\text { (error) }\end{array}$ & 15185,41 & 94 & 161,55 & - & - & - \\
\hline \multirow{6}{*}{$\begin{array}{c}\text { Kompetensi Sikap Sosial } \\
\text { Siswa }\end{array}$} & Total & 28493,07 & 102 & - & - & - & - \\
\hline & $\begin{array}{c}\text { Faktor } A \text { (Model } \\
\text { Pembelajaran) }\end{array}$ & 1040,12 & 2 & 520,06 & 8,408 & 3,093 & $H_{0}$ ditolak \\
\hline & $\begin{array}{c}\text { Faktor } B \\
\text { (Gaya Belajar) }\end{array}$ & 2487,04 & 2 & 1243,52 & 20,104 & 3,093 & $H_{0}$ ditolak \\
\hline & Interaksi $A B$ & 2171,72 & 4 & 542,93 & 8,777 & 2,469 & $H_{0}$ ditolak \\
\hline & $\begin{array}{l}\text { Residual } \\
\text { (error) }\end{array}$ & 5814,41 & 94 & 61,86 & - & - & - \\
\hline & Total & 1151,30 & 102 & - & - & - & - \\
\hline
\end{tabular}

Berdasarkan Tabel 2, disimpulkan: (1) terdapat perbedaan model pembelajaran terhadap kompetensi pengetahuan dan sikap sosial, (2) terdapat perbedaan gaya belajar terhadap kompetensi pengetahuan dan sikap sosial, (3) terdapat interaksi antara model pembelajaran dan gaya belajar terhadap kompetensi pengetahuan dan sikap sosial. Rangkuman rerata antar sel dan rerata marginal disajikan berikut.

Tabel 3 Rerata Antar Sel dan Rerata Marginal

\begin{tabular}{|c|c|c|c|c|c|c|c|c|}
\hline \multirow{3}{*}{$\begin{array}{c}\text { Model } \\
\text { Pembelajaran }\end{array}$} & \multicolumn{6}{|c|}{ Gaya Belajar } & \multirow{2}{*}{\multicolumn{2}{|c|}{$\begin{array}{c}\text { Rerata } \\
\text { Marginal }\end{array}$}} \\
\hline & \multicolumn{2}{|c|}{ Visual } & \multicolumn{2}{|c|}{ Auditorial } & \multicolumn{2}{|c|}{ Kinestetik } & & \\
\hline & $X_{1}$ & $X_{2}$ & $X_{1}$ & $X_{2}$ & $X_{1}$ & $X_{2}$ & $X_{1}$ & $X_{2}$ \\
\hline TAPPS & 76,86 & 97,79 & 74,91 & 97,18 & 75,50 & 97,13 & 75,88 & 97,42 \\
\hline GI & 66,29 & 96,79 & 72,80 & 105,60 & 61,20 & 91,60 & 66,71 & 97,85 \\
\hline Konvensional & 68,00 & 99,92 & 60,00 & 94,92 & 45,45 & 81,36 & 58,22 & 92,44 \\
\hline Rerata Marginal & 70,50 & 98,08 & 68,59 & 98,79 & 59,17 & 89,24 & & \\
\hline
\end{tabular}


Untuk selanjutnya, uji komparasi ganda menggunakan metode Scheffe'. Rangkuman uji komparasi ganda antar baris dan antar kolom disajikan pada Tabel 4 dan Tabel 5 berikut.

\begin{tabular}{ccccc}
\multicolumn{6}{c}{ Tabel 4. Rangkuman Hasil Uji Komparasi Ganda Antar Baris } \\
\hline Variabel Terikat & \multicolumn{1}{c}{$\boldsymbol{H}_{\boldsymbol{0}}$} & $\boldsymbol{F}_{\text {obs }}$ & $\boldsymbol{F}_{\text {tabel }}$ & Keputusan Uji \\
\hline $\begin{array}{c}\text { Kompetensi } \\
\text { Pengetahuan }\end{array}$ & $\mu_{11 \bullet}=\mu_{12} \bullet$ & 8,722 & 6,187 & $H_{0}$ ditolak \\
Matematika & $\mu_{11 \bullet}=\mu_{13 \bullet}$ & 33,226 & 6,187 & $H_{0}$ ditolak \\
& $\mu_{12 \bullet}=\mu_{13 \bullet}$ & 7,790 & 6,187 & $H_{0}$ ditolak \\
& $\mu_{21 \bullet}=\mu_{22} \bullet$ & 0,416 & 6,187 & $H_{0}$ diterima \\
Kompetensi & $\mu_{21 \bullet}=\mu_{23 \bullet}$ & 13,353 & 6,187 & $H_{0}$ ditolak \\
Sikap Sosial & $\mu_{22 \bullet}=\mu_{23} \bullet$ & 8,589 & 6,187 & $H_{0}$ ditolak \\
& & & &
\end{tabular}

Berdasarkan Tabel 4, uji komparasi ganda untuk $\mu_{11}=\mu_{12}$. terlihat bahwa terdapat perbedaan yang signifikan antara model pembelajaran TAPPS dan GI terhadap kompetensi pengetahuan siswa pada materi bangun ruang sisi datar. Dari rerata marginalnya dapat diketahui bahwa kompetensi pengetahuan siswa yang diberi model TAPPS lebih baik dibandingkan siswa yang diberi model GI. TAPPS memungkinkan siswa untuk melatih konsep, mengaitkannya dengan kerangka kerja yang sudah ada dan menghasilkan pemahaman materi yang mendalam. Dalam pelaksanaan pembelajaran dengan model GI, terdapat siswa dalam suatu kelompok yang tidak mau bekerjasama dengan anggota kelompoknya dan mengandalkan teman dalam kelompoknya. TAPPS model provides an opportunity for students to practice verbal skills, thoroughness in solving problems, and foster courage to express their thoughts [12]

Selanjutnya uji komparasi ganda untuk $\mu_{11} \cdot=\mu_{13}$. terlihat terdapat perbedaan yang signifikan antara model TAPPS dan konvensional. Dari rerata marginalnya diketahui bahwa kompetensi pengetahuan siswa yang diberi model TAPPS lebih baik dari siswa yang diberi model konvensional. Pada pelaksanaan pembelajaran TAPPS, siswa lebih tertarik dengan pembelajaran dan lebih bersemangat dalam belajar. Siswa bersama kelompoknya membangun pengetahuan mereka sendiri, guru hanya sebagai fasilitator. Sedangkan pada pembelajaran konvensional, siswa cenderung bosan karena guru sebagai pusat pembelajaran. Uji komparasi ganda untuk $\mu_{12} \cdot=\mu_{13}$. disimpulkan bahwa terdapat perbedaan yang signifikan antara model $G I$ dan konvensional. Dari rerata marginal diketahui bahwa kompetensi pengetahuan siswa yang diberi GI lebih baik dari yang diberi model konvensional. Hal tersebut sesuai dengan hasil penelitian sebelumnya yang menyatakan bahwa hasil belajar matematika siswa dengan model pembelajaran GI lebih baik daripada siswa yang mengikuti pembelajaran konvensional [13].

Uji komparasi ganda untuk $\mu_{21} \cdot=\mu_{22 \bullet}$, diketahui tidak ada perbedaan signifikan antara model TAPPS dan GI terhadap sikap sosial siswa. Kompetensi sikap sosial siswa dapat meningkat jika didukung oleh penerapan model pembelajaran yang tepat. Pembelajaran kooperatif dapat mengembangkan kompetensi sosial dan juga kepercayaan diri [14]. Uji komparasi ganda untuk $\mu_{21} \cdot=\mu_{23}$, terlihat terdapat perbedaan signifikan antara model TAPPS dan konvensional terhadap sikap sosial 
siswa. Dari rerata marginal didapatkan bahwa model TAPPS lebih baik dari konvensional terhadap sikap sosial siswa. Uji komparasi ganda untuk $\mu_{22 \bullet}=\mu_{23}$, terlihat terdapat perbedaan signifikan antara model GI dan konvensional terhadap sikap sosial siswa. Dari rerata marginal didapatkan bahwa model GI lebih baik dari konvensional terhadap sikap sosial siswa. Pembelajaran yang bersifat konvensional, berpusat pada guru, dan hanya menekankan pada penguasaan tingkat pemahaman yang rendah tidak akan dapat mengembangkan keterampilan berpikir tingkat tinggi dan sikap sosial [14].

Tabel 5. Rangkuman Hasil Uji Komparasi Ganda Antar Kolom

\begin{tabular}{ccccc}
\hline Variabel Terikat & $\boldsymbol{H}_{\boldsymbol{0}}$ & $\boldsymbol{F}_{\text {obs }}$ & $\boldsymbol{F}_{\text {tabel }}$ & Keputusan Uji \\
\hline $\begin{array}{c}\text { Kompetensi } \\
\text { Pengetahuan }\end{array}$ & $\mu_{1 \bullet 1}=\mu_{1 \bullet 2}$ & 0,416 & 6,187 & $H_{0}$ diterima \\
Matematika & $\mu_{1 \bullet 1}=\mu_{1 \bullet 3}$ & 13,353 & 6,187 & $H_{0}$ ditolak \\
& $\mu_{1 \bullet 2}=\mu_{1 \bullet 3}$ & 8,589 & 6,187 & $H_{0}$ ditolak \\
& $\mu_{2 \bullet 1}=\mu_{2 \bullet 2}$ & 0,154 & 6,187 & $H_{0}$ diterima \\
Kompetensi & $\mu_{2 \bullet 1}=\mu_{2 \bullet 3}$ & 21,208 & 6,187 & $H_{0}$ ditolak \\
Sikap Sosial & $\mu_{2 \bullet 2}=\mu_{2 \bullet 3}$ & 23,089 & 6,187 & $H_{0}$ ditolak \\
\hline
\end{tabular}

Berdasarkan Tabel 5, uji komparasi ganda untuk $\mu_{1 \bullet 1}=\mu_{1 \cdot 2}$ terlihat bahwa tidak ada perbedaan signifikan antara siswa visual dan auditorial terhadap kompetensi pengetahuan matematika siswa. Untuk $\mu_{1 \bullet 1}=\mu_{1 \bullet 3}$, terdapat perbedaan signifikan antara siswa tipe visual dan kinestetik terhadap kompetensi pengetahuan. Dari rerata marginal diketahui bahwa tipe visual lebih baik dari tipe kinestetik. Penelitian menyimpulkan bahwa pada materi bangun ruang, prestasi matematika gaya belajar visual lebih baik daripada kinestetik [15].

Dari $\mu_{1 \cdot 2}=\mu_{1 \bullet 3}$ terlihat perbedaan signifikan antara siswa auditorial dan kinestetik. Dari rerata marginal diketahui auditorial lebih baik dari kinestetik. Pada kedua tipe tersebut siswa mengalami kesulitan yang sama dibanding dengan tipe visual pada materi bangun ruang sisi datar. Namun biasanya siswa auditorial pandai sehingga mudah menyesuaikan diri. Sedangkan tipe kinestetik membutuhkan alat peraga untuk memahami materi, sedangkan dalam penelitian ini tidak digunakan alat peraga.
Uji komparasi ganda untuk $\mu_{2 \bullet 1}=\mu_{2 \bullet 2}$, tidak terdapat perbedaan signifikan antara siswa dengan gaya belajar tipe visual dan auditorial terhadap sikap sosial siswa. Untuk $\mu_{2 \bullet 1}=\mu_{2 \cdot 3}$, terlihat perbedaan signifikan antara siswa tipe visual dan kinestetik. Dari rerata marginal diketahui tipe visual menghasilkan kompetensi sikap sosial lebih baik dari kinestetik. Sesuai cirinya, siswa dengan tipe visual mempunyai kesadaran untuk berinteraksi dan bersikap pada objek sosial lebih baik dibandingkan dengan tipe kinestetik. Untuk $\mu_{2 \bullet 2}=\mu_{2 \bullet 3}$, terdapat perbedaan signifikan antara siswa tipe auditorial dengan kinestetik. Dari rerata marginalnya diperoleh kompetensi sikap sosial tipe auditorial lebih baik dari kinestetik. Salah satu ciri siswa auditorial lebih suka belajar dengan mendengarkan dan mengingat apa yang didiskusikan daripada yang dilihat. Hal tersebut mengindikasikan tipe auditorial mempunyai sikap sosial yang lebih baik.

Lebih lanjut, untuk uji antar sel dari penelitian ini disimpulkan bahwa: (1) Pada model TAPPS dan GI, kompetensi 
pengetahuan ketiga tipe gaya belajar sama baiknya. Sedang pada konvensional, siswa tipe visual lebih baik dari kinestetik, serta tipe visual dan auditorial sama baiknya. (2) Pada model TAPPS dan GI, sikap sosial ketiga tipe gaya belajar sama baiknya. Sedang pada konvensional, sikap sosial siswa tipe visual dan auditorial sama baiknya, serta keduanya lebih baik dari kinestetik. (3) Pada siswa tipe visual dan auditorial, kompetensi pengetahuan ketiga model sama. Sedang pada kinestetik, model TAPPS dan GI sama baiknya, serta TAPPS lebih baik dari konvensional. (4) Pada siswa tipe visual dan auditorial, sikap sosial ketiga model sama, Sedang pada kinestetik, TAPPS dan GI sama baiknya, serta TAPPS lebih baik dari konvensional. Pada saat pandemi Covid-19 ini, siswa belajar dari rumah, sehingga kompetensi pengetahuan dan sikap sosial siswa tidak sepenuhnya dapat diamati oleh guru. Namun demikian, ketika sekolah tatap muka kembali dibuka diharapkan penerapan model pembelajaran dalam penelitian ini dapat menjadi acuan bagi guru dengan memperhatikan gaya belajar masing-masing siswa. Guru juga tetap dapat mengetahui gaya belajar atau sikap sosial siswa dengan menggunakan google form dengan pernyataan yang disesuaikan dengan kondisi saat ini.

\section{SIMPULAN}

Simpulan dalam penelitian ini sebagai berikut. (1) TAPPS menghasilkan kompetensi pengetahuan yang lebih baik daripada $G I$ dan konvensional, dan $G I$ lebih baik dari konvensional. (2) TAPPS dan GI menghasilkan kompetensi sikap sosial yang sama, serta keduanya lebih baik dari konvensional. (3) Siswa tipe visual dan auditorial menghasilkan kompetensi pengetahuan yang sama baiknya, serta keduanya lebih baik dari kinestetik. (4) Siswa tipe visual dan auditorial menghasilkan kompetensi sikap sosial yang sama baiknya, serta keduanya lebih baik dari kinestetik. (5) Pada TAPPS dan GI, kompetensi pengetahuan ketiga tipe gaya belajar sama baiknya. Sedang pada konvensional, siswa tipe visual lebih baik dari kinestetik, serta tipe visual dan auditorial sama baiknya. (6) Pada TAPPS dan GI, sikap sosial ketiga tipe gaya belajar sama baiknya. Sedang pada konvensional, sikap sosial siswa tipe visual dan auditorial sama baiknya, serta keduanya lebih baik dari kinestetik. (7) Pada siswa tipe visual dan auditorial, kompetensi pengetahuan ketiga model sama. Sedang pada kinestetik, TAPPS dan GI sama baiknya, serta TAPPS lebih baik dari konvensional. (8) Pada siswa tipe visual dan auditorial, sikap sosial ketiga model sama, Sedang pada kinestetik, TAPPS dan GI sama baiknya, serta TAPPS lebih baik dari konvensional.

\section{DAFTAR PUSTAKA}

[1] I. P. A. A. Payadnya, I. B. K. Perdata, dan P. Y. Antara, "Perbedaan hasil belajar matematika siswa yang menggunakan model pembelajaran konvensional dengan model pembelajaran kooperatif tipe TAI (Team Assisted Individualization) berbantuan media powerpoint," AKSIOMA J. Mat. dan Pendidik. Mat., vol. 10, no. 2, pp. 285-293, 2019.

[2] S. Hadi dan Novaliyosi, "TIMSS Indonesia (Trends in International Mathematics and Science Study)," Pros. Semin. Nas. Call Pap. Progr. Stud. Magister Pendidik. Mat. Univ. Siliwangi, pp. 562-569, 2019.

[3] I. A. D. Virani, P. N. Riastini, dan M. Suarjana, "Deskripsi Sikap Sosial pada Siswa Kelas IV SD Negeri 4 Penarukan Kecamatan Buleleng Kabupaten Buleleng," PGSD Univ. Pendidik. Ganesha, vol. 4, no. 1, p. 1, 2016.

[4] U. N. Halimah, "Dampak Dopari terhadap Sikap Sosial Siswa SDN 02 
Mojorejo-Taman-Kota Madiun," Gulawentah: Jurnal Stud. Sos., vol. 2, no. 2, p. 130, 2017.

[5] P. R. Diningrum, E. Azhar, dan A. Faradillah, "Hubungan Disposisi Matematis terhadap Kemampuan Komunikasi Matematis Siswa Kelas VII di SMP Negeri 24 Jakarta," Pendidik. Mat., vol. 01, pp. 352-364, 2018.

[6] P. D. Pratiwi, I. B. P. Mardana, dan I. N. P. Suwindra, "Model Pembelajaran Kooperatif-Jigsaw dalam Meningkatkan Pembelajaran Fisika terhadap Sikap Sosial, Sikap Spiritual, dan Prestasi Belajar Siswa," Jurnal Pendidikan Fisika Undiksha, vol. 7, no. 2, pp. 74-84, 2017.

[7] L. Armila, R. Asnawati, dan S. Sutiarso, "Efektivitas Pembelajaran Kooperatif Tipe TAPPS Ditinjau dari Kemampuan Pemecahan Masalah Matematis Siswa," Jurnal Pendidikan Matematika Unila, vol. 5, no. 8, pp. 902-913, 2017.

[8] T. Suprianto, S. H. Noer, dan U. Rosidin, "Pengembangan Model Pembelajaran Group Investigation Berbantuan Soal Open Ended untuk Meningkatkan Kemampuan Berpikir Relfektif Matematis," AKSIOMA, vol. 9, no. 1, pp. 72-85, 2020.

[9] R. Wulan, A. Sarwandianto, N. Alamsyah, and A. A. Rakhman Awaludin, "Android-Based Expert System Application to Determine Math Learning Styles of Elementary School Students in Surakarta," SAR J. - Sci. Res., vol. 3, no. 2, pp. 65-70, 2020.

[10] Y. Wahyuni, "Identifikasi Gaya Belajar (Visual, Auditorial, Kinestetik) Mahasiswa Pendidikan Matematika Universitas Bung
Hatta," JPPM, vol. 10, no. 2, pp. 128-132, 2017.

[11] E. A. R. Pinahayu, Mardiyana, dan I. Slamet, "Eksperimentasi Model Pembelajaran Discovery Learning, Problem Based Learning, dan Think Pair Share dengan Pendekatan Saintifik terhadap Kompetensi Pengetahuan dan Sikap Sosial Ditinjau dari Gaya Belajar Siswa," Jurnal Elektronik Pembelajaran Matematika vol. 3, no. 7, pp. 796810, 2015.

[12] N. Dwi dan P. Hendikawati, "The Mathematical Problem Solving Ability of Student on Learning with Thinking Aloud Pair Problem Solving (TAPPS) Model in Term of Student Learning Style," Unnes J. Math. Educ., vol. 7, no. 1, pp. 1-7, 2018.

[13] S. R. Wirdayat, M. Imamuddin, dan M. Kamal, "Hasil Belajar Matematika Siswa dengan Menggunakan Model Pembelajaran Kooperatif Tipe Group Investigation (GI) pada Siswa Kelas VII SMP N 3 Tigo Nagari Tahun Pelajaran 2018/2019," JURING, vol. 2, no. 2, p. 165, 2019.

[14] M. S. Bialangi dan I. N. Kundera, "Pengembangan sikap sosial dalam pembelajaran biologi : kajian potensi pembelajaran kooperatif," Proceeding Biol. Educ. Conf., vol. 15, no. 1, pp. 138-145, 2018.

[15] E. Mahendrawan, "Eksperimentasi Model Pembelajaran Problem Based Instruction dan Reciprocal Teaching pada Materi Bangun Ruang Ditinjau dari Gaya Belajar Siswa Kelas VIII SMP Negeri Se-Kabupaten Wonogiri Tahun Pelajaran 2013/2014," UNS, 2014. 